\title{
Перспективы развития экономики Республики Бурятия 1
}

\begin{abstract}
A.О. БАРАНОВ, доктор эКономических наук, Институт экономики и организации промышленного производства СО РАН, Новосибирский национальный исследовательский государственный университет, Новосибирск. E-mail: baranov@ieie.nsc.ru
\end{abstract}

З.Б.-Д. дондокОВ, доктор экономических наук, Бурятский научный центр СО РАН, Улан-Удэ. E-mail: dzorikto@mail.ru

В.Н. ПАВЛОВ, доктор технических наук, Институт экономики и организации промышленного производства СО РАН, Новосибирск.

E-mail: victor_n_pavlov@mail.ru

В.И. Суслов, член-корреспондент РАН, доктор экономических наук, Институт экономики и организации промышленного производства СО РАН, Новосибирский национальный исследовательский государственный университет, Новосибирск. E-mail: suslov@ieie.nsc.ru

В статье исследуется развитие экономики Республики Бурятия в 20072017 гг., приводятся и анализируются результаты прогнозных расчетов и развития на период до 2021 г. в двух вариантах - базовом и оптимистическом. Прогнозные расчеты выполнены с использованием разработанной авторами динамической межотраслевой модели экономики Республики Бурятия с нечеткими параметрами. В работе показано, что при благоприятных макроэкономических условиях и резком росте инвестиций в основной капитал возможно существенное ускорение экономического роста в Бурятии. Обсуждаются конкретные проекты, которые позволят ускорить экономический рост в республике.

Ключевые слова: анализ и прогнозирование экономики региона, Республика

Бурятия, динамические межотраслевые модели

\section{Исследования экономики Республики Бурятия}

Различные аспекты развития экономики Республики Бурятия рассматриваются в работах многих российских исследователей. Проблемы, тенденции и основные направления перспективного развития отраслей и секторов экономики республики наиболее полно и системно отражены в монографии «Стратегия регионального развития: Республика Бурятия - 2015» [Стратегия..., 2005]. В этой фундаментальной работе отдельно выделены главы, посвященные «байкальскому фактору» развития и экологической политике. Прогнозные расчеты были выполнены с использованием региональной макроэкономической модели, разработанной в ИСЭМ СО РАН.

${ }^{1}$ Работа выполнена при финансовой поддержке РФФИ, проект 16-02-00650. 
В ряде статей рассматриваются вопросы разработки стратегических ориентиров развития Бурятии. Так, И.Г. Сангадиевой выделены сильные и слабые стороны экономики региона, которые могут стать основой для определения целей и задач приоритетных направлений его развития, исследованы особенности формирования системы институционального обеспечения стратегического планирования [Сангадиева, 2016].

Эксперты Беломестнова В.Г. и Хардаев К. П. [Беломестнов, Хардаев, 2016] рассматривают подходы к формированию стратегии социально-экономического развития республики, описывают концепцию формирования «полихромной» эколого-ориентированной экономики и социо-эколого-экономического замещения ресурсов, а также возможные механизмы реализации региональной стратегии. В работе Булатовой Н.Н. и Тихоновой П. В. [Булатова, Тихонова, 2017] проведен анализ ключевых проблем развития Республики Бурятия и выделены основные направления государственной региональной политики, способствующие их решению. Предложен перечень мероприятий по преодолению негативных тенденций и ресурсных ограничений на основе поддержания существующих производств, привлечения крупных инвесторов, развития экологических территориально-отраслевых кластеров.

В исследованиях, посвященных минерально-сырьевому комплексу Бурятии, выделены факторы, препятствующие его развитию: суровый континентальный климат, сложный рельеф с высокой сейсмичностью, слабая транспортная инфраструктура [Дондоков и др., 2015; Таханова, Шаралдаева, 2016]. Отмечено, что особые экологические условия БПТ приводят не только к удорожанию инвестиционных проектов, но и запрету на освоение отдельных месторождений.

В последние годы в исследованиях, посвященных перспективам развития Республики Бурятия, значительное внимание уделяется проблемам создания экономического коридора Китай-Монголия-Россия (ЭККМР). Его центральная ось проходит по территории Бурятии: Тяньцзинь - Пекин - Эрэн-Хото (Эрлянь) - Улан-Батор - Наушки/Кяхта - Улан-Удэ. Рассматриваются вопросы сопряжения и гармонизации проектов Евразийского экономического союза и Экономической зоны Великого Шелкового пути, дается экспертная характеристика программы создания 
ЭККМР [Атанов, 2017; Борисов и др., 2017; Дондоков и др., 2016]. Особое внимание уделено вопросам международного сотрудничества по развитию транспортной инфраструктуры и формированию единого евроазиатского транспортного пространства [Булатова, 2017, Булатова и др., 2017].

К сожалению, большинство указанных работ носит в основном описательный характер, без проведения расчетов по оценке перспектив развития экономики республики. По нашему мнению, для выполнения комплексного анализа и прогнозирования развития региона необходимо использование экономико-математических методов, позволяющих учесть межотраслевые связи.

\section{Экономика Бурятии в 2007-2017 гг. ${ }^{2}$}

Республика Бурятия (РБ) на протяжении длительного периода характеризуется значительным отставанием от среднероссийского уровня по основным показателям социально-экономического развития. Причем, несмотря на все усилия, это отставание год от года увеличивается. Так, если в 1998 г. валовой региональный продукт (ВРП) на душу населения в Бурятии составил $71,2 \%$ от среднего по РФ, то в 2007 г. - уже 56,8\%, а в 2016 г. - всего 42,9\% (табл. 1 ).

Таблица 1. Валовой региональный продукт на душу населения в РФ в 1998-2016 гг., тыс. руб. ${ }^{3}$

\begin{tabular}{|l|c|c|c|c|c|}
\hline \multicolumn{1}{|c|}{ Показатель } & $\mathbf{1 9 9 8}$ & $\mathbf{2 0 0 7}$ & $\begin{array}{c}\mathbf{2 0 0 7} \text { г. } \\
\text { к 1998 г., } \\
\text { в разах }\end{array}$ & $\mathbf{2 0 1 6}$ & $\begin{array}{c}\mathbf{2 0 1 6} \text { г. } \\
\text { к 2007 г., раз }\end{array}$ \\
\hline Российская Федерация & 15,3 & 195,8 & 12,95 & 472,1 & 2,41 \\
\hline Сибирский федеральный округ & 14,6 & 154,7 & 10,59 & 369,1 & 2,38 \\
\hline Республика Бурятия & 10,9 & 111,3 & 10,21 & 202,6 & 1,82 \\
\hline
\end{tabular}

То же самое происходит с другими ключевыми показателями социально-экономического развития. За последние 10 лет отставание Республики Бурятия от средних по России и СФО значений заметно усилилось (табл. 2).

\footnotetext{
${ }^{2}$ На момент подготовки статьи ряд показателей развития экономики РБ за 2017 г. были предварительными и по этой причине в анализ не включены.

${ }^{3}$ Составлено по данным Росстата [Эл. ресурc] URL: http://www.gks.ru/wps/wcm/connect/ rosstat_main/rosstat/ru/statistics/accounts/\# (дата обращения: 10.07.2018).
} 
Таблица 2. Показатели социально-экономического развития Республики Бурятия в сравнении со средними показателями РФ в 2007 г., 2017 г.

\begin{tabular}{|c|c|c|c|c|c|}
\hline \multirow{2}{*}{ № } & \multirow{2}{*}{ Показатели в расчете на душу населения } & \multicolumn{2}{|c|}{2007} & \multicolumn{2}{|c|}{2017} \\
\hline & & $\mathbf{P \Phi}$ & РБ & $\mathbf{P \Phi}$ & РБ \\
\hline 1 & $\begin{array}{l}\text { Объем отгруженной продукции, выполненных работ } \\
\text { и услуг, по ВЭД «Добыча полезных ископаемых», } \\
\text { тыс. руб. }\end{array}$ & 31,5 & 5,1 & 93,6 & 22,0 \\
\hline 2 & $\begin{array}{l}\text { Объем отгруженной продукции, выполненных работ } \\
\text { и услуг, по ВЭД «Обрабатывающие производства», } \\
\text { тыс. руб. }\end{array}$ & 98,3 & 24,8 & 254,2 & 58,1 \\
\hline 3 & Зерно (в весе после доработки), тыс. т & 576,6 & 85,0 & 913,1 & 39,7 \\
\hline 4 & Скот и птица на убой (в убойном весе) тыс. т & 40,1 & 29,3 & 99,4 & 70,1 \\
\hline 5 & Инвестиции в основной капитал, тыс. руб. & 46,6 & 21,5 & 108,7 & 42,1 \\
\hline 6 & $\begin{array}{l}\text { Объем работ, выполненных по ВЭД «Строитель- } \\
\text { ство», тыс. руб. }\end{array}$ & 23,1 & 9,4 & 51,3 & 28,1 \\
\hline 7 & Оборот розничной торговли, тыс. руб. & 76,4 & 56,7 & 202,9 & 173,0 \\
\hline 8 & Объем платных услуг, тыс. руб. & 24,1 & 14,2 & 60,1 & 43,4 \\
\hline 9 & Уровень общей безработицы,\% & 6,1 & 12,9 & 5,1 & 9,7 \\
\hline 10 & $\begin{array}{l}\text { Номинальная начисленная среднемесячная зар- } \\
\text { плата, руб. }\end{array}$ & 13,6 & 11,5 & 38,0 & 31,1 \\
\hline
\end{tabular}

Источник: составлено по данным Росстата 4 .

Основные причины негативного развития экономики РБ в 2007-2017 гг. целесообразно разделить на объективные и субъективные. К объективным причинам можно отнести следующие.

$\sqrt{ }$ Развитие экономики республики в целом шло по инерционному сценарию путем использования созданных в прошлом производственных мощностей. Произошел спад производства на крупнейших промышленных предприятиях - локомотивовагоноремонтном заводе, авиационном заводе, приборостроительном объединении. В последние годы эти предприятия испытывают значительные проблемы, связанные с сужением рынка сбыта, низкими темпами обновления ассортимента продукции, высокой степенью износа основных фондов.

$\sqrt{ }$ Рост тарифов на перевозку массовых грузов в условиях отдаленности Бурятии от основных рынков сбыта и морских портов привел к снижению конкурентоспособности и, соответственно,

${ }^{4}$ Регионы России. Социально-экономические показатели. 2008: Стат. сб. / Росстат. - М., 2008. 999 с.; Социально-экономическое положение России - 2017 год [Эл. ресурс]. URL: http://www.gks.ru/free_doc/doc_2017/social/osn-12-2017.pdf; Социально-экономическое положение России - январь 2018 года [Эл. ресурc].URL: http://www.gks.ru/free_doc/ doc_2018/social/osn-01-2018.pdf (дата обращения: 15.07.2018). 
объемов производства на предприятиях по добыче полезных ископаемых, лесозаготовке, производству металломостовых конструкций.

$\sqrt{ }$ K середине 2000-х годов на экономику республики начали оказывать большое влияние ограничения на хозяйственную деятельность, введенные в связи с вступлением в силу федерального закона «Об охране озера Байкал» ${ }^{5}$. В центральной экологической зоне Байкальской природной территории запрещена заготовка древесины, разведка и разработка новых месторождений, строительство зданий и сооружений. Были закрыты фермы крупного рогатого скота, кошары, производственные объекты рыболовства и рыбопереработки. По оценкам экспертов, годовые потери экономики республики от «байкальского фактора» превышают 10\% ВРП [Стратегия.., 2015].

Субъективные причины негативного развития экономики республики во многом связаны с ошибками и просчетами, допущенными правительством Бурятии. Во-первых, неправильно были определены приоритетные для развития отрасли: минерально-сырьевой, лесопромышленный и агропромышленный комплексы ${ }^{6}$. В условиях жестких экологических ограничений отрасли первичного сектора экономики не имеют особых перспектив развития. При этом республике не удалось сохранить ведущие предприятия пищевой промышленности - мелькомбинат, макаронную фабрику, а также производителя алкогольной продукции ОАО «Байкалфарм» - одного из ее крупнейших налогоплательщиков.

Во-вторых, из-за несогласованности действий с инвесторами и федеральными ведомствами не были реализованы крупные инвестиционные проекты, включая строительство Мокской ГЭС, модернизацию Улан-Удэнской ТЭЦ-2, создание лесопромышленного комплекса «Байкал-Нордик», строительство Озерного ГОК и железной дороги к нему. Из 12 заявленных инвестиционных проектов в минерально-сырьевом секторе в настоящее время реализуется лишь один - строительство промышленного предприятия по добыче урана на ОАО «Хиагда».

\footnotetext{
${ }^{5}$ Федеральный закон от 01.05.1999 № 94-Ф3 «Об охране озера Байкал».

${ }^{6}$ Постановление Правительства Республики Бурятия от 15 декабря 2007 г. № 410 «О Стратегии социально-экономического развития Республики Бурятия до 2025 года».
} 
В-третьих, после 2013 г. Республика Бурятия фактически «выпала» из государственных и федеральных целевых программ по развитию территорий. Так, из 511,8 млрд руб., предусмотренных на финансирование государственной программы РФ «Социально-экономическое развитие Дальнего Востока и Байкальского региона» на реализацию мероприятий в Республике Бурятия выделено лишь 7,1 млрд руб.7

Вместе с тем в 2017 г. наметились определенные признаки улучшения состояния экономики Республики Бурятия 8 . Впервые за пять лет удалось переломить тенденцию сокращения инвестиций в основной капитал, объем которых вырос на $19 \%$ и составил 41,5 млрд руб. ${ }^{9}$ Объем внебюджетных инвестиций в 2017 г. вырос на 5,8 млрд руб. и составил 29,6 млрд руб. Существенный вклад в эту динамику внес «Улан-Удэнский авиационный завод», продолжающий программу технического и технологического развития. В четыре раза выросли инвестиции в модернизацию мощностей ОАО «Селенгинский ЦКК». Инвестиции в добычу полезных ископаемых выросли за год на 28,6\% и составили 5,8 млрд руб. В транспортный сектор было привлечено 8,8 млрд руб., в энергетику - 3,2 млрд руб.

Бурятия включилась в ряд федеральных приоритетных проектов - «Современная образовательная среда», «Развитие санитарной авиации», «Безопасные и качественные дороги», «Формирование комфортной городской среды». В целом в 2017 г. объем бюджетных инвестиций вырос на 2,3 млрд руб. и составил 11,9 млрд руб., из них инвестиции из федерального бюджета составили 7,8 млрд руб.

Положительная динамика в инвестиционной деятельности в значительной степени обусловлена активной лоббистской работой нового главы Республики Бурятия А. С. Цыденова, до 7 февраля 2017 г. занимавшего пост заместителя министра транспорта РФ.

\footnotetext{
${ }^{7}$ Постановление Правительства Российской Федерации от 15 апреля 2014 года №308 «Об утверждении государственной программы Российской Федерации «Социальноэкономическое развитие Дальнего Востока и Байкальского региона».

${ }^{8}$ Ежегодный отчет Правительства Республики Бурятия о результатах деятельности. Итоги за 2017 год URL: http://egov-buryatia.ru/press_center/at-first-watch/detail.php? ID=13096 (дата обращения: 13.07.2018).
} 


\section{Прогноз развития экономики Бурятии на 2018-2021 гг.}

Прогнозирование развития экономики Республики Бурятия осуществлялось с использованием 32-отраслевой динамической межотраслевой модели (ДММ) с нечеткими параметрами [Баранов и др., 2016], разработанной на базе системы КАМИН [Баранов, Павлов, 2007]. При построении прогноза существенной вариации были подвергнуты такие экзогенные параметры, как инвестиции в основной капитал и сальдо ввоза-вывоза экономики РБ в прогнозном периоде ${ }^{10}$. Расчеты были проведены для двух вариантов - базового и оптимистического.

Основные допущения базового варианта прогноза для Республики Бурятия.

1. Предполагается, что в экономике России в период 20182021 гг. не произойдет заметного ускорения экономического роста и будет реализован инерционный вариант развития, характеризующийся пассивной монетарной и фискальной политикой.

2. Экономическое развитие Республики Бурятия характеризуется значительной инерционностью: общие для экономики России тенденции в республике проявляются, как правило, с запаздыванием примерно на 1-2 года. С 2016 г. в большинстве отраслей Бурятии начался полномасштабный спад производства. Кризисные явления в значительной степени были обусловлены снижением выпуска продукции крупнейшими промышленными предприятиями, включая Улан-Удэнский авиазавод, на котором произошло резкое снижение экспортного портфеля заказов. Поэтому в базовом варианте прогнозируются невысокие темпы роста ВРП и валового выпуска в 2018-2019 гг. Более значительные темпы роста этих ключевых макропоказателей ожидаются лишь в 2020-2021 гг. Наибольшее значение для формирования экономического роста в Бурятии имеют «Оптовая и розничная торговля» $(15,8 \%$ в ВРП в 2016 г.), «Транспорт и связь» $(14 \%$ в ВРП) и обрабатывающие производства (12,3\% ВРП). Вместе

\footnotetext{
${ }^{10}$ Анализ математических и технических особенностей прогнозирования экономики РБ с использованием ДММ с нечеткими параметрами не является предметом данной статьи и будет выполнен авторами в другой публикации.
} 
эти виды экономической деятельности формируют более $42 \%$ ВРП республики ${ }^{11}$.

3. Негативное влияние на развитие республики оказало снижение объема инвестиций в 2014-2016 гг. В наибольшей степени это сказалось на строительстве. Положительные темпы роста инвестиций в основной капитал и валового выпуска строительства возобновились лишь в 2017 г., когда объем валового выпуска строительства в сопоставимых ценах возрос на 7,5\%.

В базовом варианте предполагается продолжение роста инвестиций в основной капитал и валового выпуска строительства на уровне 2-4\% в год в 2018-2021 гг. (см. табл. 4). Прирост инвестиций будет обеспечен главным образом за счет реализации ряда крупных инвестиционных проектов, поддержанных Правительством Российской Федерации и направленных на развитие транспортной и энергетической инфраструктуры, а также проектов по лесопереработке, созданию транспортно-логистических центров, объектов туристско-рекреационной сферы и переработки отходов, финансируемых с привлечением средств инвесторов из КНР, Японии, Республики Корея, Индии.

Основные предположения оптимистического варианта прогноза для Республики Бурятия.

1. Предполагается, что в России в прогнозном периоде будут проводиться более мягкая кредитно-денежная и активная фискальная политика, способствующая ускорению экономического роста. Более благоприятные макроэкономические условия окажут позитивное воздействие на развитие экономики республики. Предполагается, что Центральный банк России под давлением обстоятельств (существенное снижение инфляции, низкий экономический рост в 2017 г. и в первой половине 2018 г.) смягчит кредитно-денежную политику. Мы не исключаем, что изменение монетарной политики ЦБ РФ может произойти и в результате «ручного управления» экономикой, так как темп экономического роста в первой половине 2018 г. (прирост ВВП 1,7\%) был примерно в три раза ниже его величины, необходимой для выполнения новых майских указов В. Путина, включающих рост экономики России к середине 2020-х годов (2025 г.) в 1,5 раза.

\footnotetext{
${ }^{11}$ Отраслевая структура валовой добавленной стоимости субъектов Российской Федерации в 2016 г., Республика Бурятия, URL: http://www.gks.ru/free_doc/new_site/ vvp/tab-vrp2.htm (дата обращения: 03.07.2018).
} 
2. Будет достигнута устойчивая положительная динамика увеличения объемов производства в добывающей промышленности за счет реализации крупных проектов, включая увеличение добычи угля на Никольском месторождении $\mathrm{AO}$ «Разрез Тугнуйский», прирост объемов производства урана АО «Хиагда».

В деревообрабатывающей промышленности планируется создание новых производств, модернизация мощностей в рамках реализации инвестиционных проектов. Развитие целлюлознобумажного производства связано с модернизацией ОАО «Селенгинский ЦКК» в рамках приоритетного инвестиционного проекта в области освоения лесов, в соответствии с которым предполагается увеличение выпуска картона не менее чем на $25 \%$ для реализации в КНР.

3. Предусматривается освоение новых изделий, расширение номенклатуры выпускаемой продукции на предприятиях машиностроения Бурятии. Так, на базе Улан-Удэнского авиазавода осваивается выпуск вертолета Ка-226ТМ с началом серийного производства в 2019 г. Уже заключены контракты на поставку продукции предприятия, в том числе на экспорт в Индию. Кроме того, имеется поддержка Президента России по организации производства на этом заводе легкомоторных многоцелевых самолетов «Байкал» (ТВС-2ДТС). На Улан-Удэнском приборостроительном производственном объединении в соответствии с соглашением между Правительством Республики Бурятия и ПАО «Россети» запущено производство интеллектуальных систем контроля и учета электроэнергии.

4. Предполагается увеличение объемов инвестиций, направленных на реализацию крупных инвестиционных проектов в региональном АПК, включая наращивание производственной мощности ООО «Свинокомплекс "Восточно-Сибирский", экспортирующего продукцию в Монголию. На конец 2019 г. запланирован выход на полную мощность Байкальского ликероводочного завода, расположенного в промышленном парке г. Улан-Удэ.

5. Планируется усиление экономического взаимодействия с КНР и Монголией, включая увеличение транзитных перевозок по Транссибирской магистрали и федеральной автотрассе «Байкал», строительство транспортно-логистических комплексов в г. Улан-Удэ и в г. Кяхте. Правительствами России и Монголии подписано соглашение об условиях железнодорожного транзита, 
направленное на облегчение доставки к морю монгольских грузов через российские порты Дальнего Востока, дополнительную загрузку и более выгодное использование транзитных мощностей российских железных дорог. В соответствии с соглашением между Правительством Республики Бурятия, ОАО «РЖД» и компанией «СГ-транс» планируется создание грузового хаба на станции Тальцы, объединяющего железнодорожные и автомобильные перевозки по внутренним направлениям и в Китай.

6. Реконструкция взлетной полосы в аэропорту г. Улан-Удэ и открытие новых авиационных маршрутов создадут условия для увеличения объемов пассажирских и грузовых авиаперевозок в РБ. В 2017 г. аэропорт столицы Бурятии включен в число аэропортов со статусом пятой степени свободы, «открытого неба» наряду с такими аэропортами, как Сочи, Владивосток и Калининград. Открывается потенциал развития маршрутной сети из городов Китая, Монголии и Европы через Улан-Удэ.

7. Создание туристического маршрута «Великий чайный путь» будет способствовать увеличению потоков китайских туристов, развитию сети гостиниц, предприятий общественного питания, туристических баз. Данный проект, включенный в Программу создания экономического коридора Китай-Монголия-Россия, имеет для Республики Бурятия важнейшее значение. Правительством республики совместно с заинтересованными бизнес-структурами реализуются проекты по созданию туристской инфраструктуры, организации культурных, гастрономических и историко-познавательных мероприятий.

8. Большое значение имеет принятое новым руководством Бурятии решение о возрождении проекта по созданию ОЭЗ туристско-рекреационного типа «Байкальская гавань» на территории Прибайкальского района с привлечением средств инвесторов из Китая и Индии. В связи с этим предполагается ускоренное развитие в таких отраслях, как «Гостиницы и рестораны», «Здравоохранение и предоставление социальных услуг», «Транспорт и связь».

9. Ускоренное развитие отраслей по производству услуг и реализация вышеупомянутых проектов потребуют восстановления инвестиционного комплекса в республике, ускоренного роста инвестиций в основной капитал и отрасли «Строительство». Более мягкая кредитно-денежная политика, проводимая в рамках 
оптимистического варианта Банком России на макроуровне, приведет к снижению ставок кредитования и будет также содействовать оживлению регионального инвестиционного процесса.

\section{Результаты прогнозных расчетов}

По базовому и оптимистическому вариантам прогнозируются положительные темпы роста валового выпуска и ВРП в каждом году прогнозного периода. За период 2018-2021 гг. ВРП экономики РБ возрастет по базовому варианту на 9,1\%, что примерно равно темпам прироста ВВП экономики России согласно прогнозу Минэкономразвития РФ в предположении, что в 2021 г. сохранится темп прироста ВВП 2020 г. ${ }^{12}$ По оптимистическому варианту темп прироста ВРП равен 15\%. Инвестиции в основной капитал увеличатся на 13\% и 20,8\% соответственно, в обоих вариантах улучшатся показатели эффективности производства материалоемкость и фондоемкость валового выпуска (табл. 3).

В целом перспективы развития экономики Республики Бурятия в значительной степени связаны с реализацией на ее территории федеральных программ, успешным «встраиванием» в них мероприятий по социально-экономическому развитию республики с максимальным учетом ключевых особенностей региона. Необходимо отметить также, что более высокие по сравнению с базовым вариантом темпы роста экономики РБ могут быть достигнуты при улучшении макроэкономической ситуации [Баранов и др., 2017]. Оптимистический вариант прогноза может быть реализован на практике при условии выполнения тех инвестиционных планов, которые наметило руководство республики в промышленности, АПК, строительстве, дорожной и туристической сфере, в области информатизации и связи ${ }^{13}$.

В сфере туризма будет осуществляться строительство объектов туристской инфраструктуры, лечебно-оздоровительных, туристско-рекреационных, гостиничных, административно-деловых комплексов, в том числе на территориях автотуристических кластеров.

\footnotetext{
12 Прогноз социально-экономического развития Российской Федерации на 2018 г. и на плановый период 2019-2020 гг. М.: Минэкономразвития РФ, 2017. С. 9.

${ }^{13}$ О прогнозе социально-экономического развития Республики Бурятия на 2018 год и на плановый период 2019 и 2020 годов. URL: http://docs.cntd.ru/document/450361500 (дата обращения: 22.07.2018).
} 
Таблица 3. Темп роста региональных показателей экономики Республики Бурятия в 2018-2021 гг., \%

\begin{tabular}{|l|c|c|c|c|c|}
\hline \multicolumn{1}{|c|}{ Показатель } & $\mathbf{2 0 1 8}$ & $\mathbf{2 0 1 9}$ & $\mathbf{2 0 2 0}$ & $\mathbf{2 0 2 1}$ & $\begin{array}{c}\mathbf{2 0 1 8} \text { - } \\
\mathbf{2 0 2 1} \text { гг. }\end{array}$ \\
\hline Валовой выпуск - всего & & & & & \\
\hline базовый вариант & 100,5 & 101,2 & 101,9 & 102,5 & 106,4 \\
\hline оптимистический вариант & 101,6 & 102,2 & 103,4 & 104,3 & 112,0 \\
\hline $\begin{array}{l}\text { Производство средств производства и проме- } \\
\text { жуточных услуг }\end{array}$ & & & & \\
\hline базовый вариант & 100,6 & 101,1 & 101,6 & 102,0 & 105,4 \\
\hline оптимистический вариант & 101,7 & 102,1 & 103,2 & 103,9 & 111,4 \\
\hline $\begin{array}{l}\text { Производство предметов потребления и услуг дляя } \\
\text { домашних хозяйств }\end{array}$ & & & & \\
\hline базовый вариант & 100,4 & 101,4 & 102,4 & 103,3 & 107,8 \\
\hline оптимистический вариант & 101,4 & 102,4 & 103,7 & 104,9 & 112,9 \\
\hline Валовой региональный продукт & & & & & \\
\hline базовый вариант & 101,1 & 101,9 & 102,6 & 103,2 & 109,1 \\
\hline оптимистический вариант & 102,2 & 102,9 & 104,1 & 105,0 & 115,0 \\
\hline Инвестиции в основной капитал & & & & & \\
\hline базовый вариант & 102,3 & 102,5 & 103,6 & 104,0 & 113,0 \\
\hline оптимистический вариант & 103,2 & 104,5 & 105,7 & 106,0 & 120,8 \\
\hline Основные фонды & & & & & \\
\hline базовый вариант & 100,6 & 100,8 & 101,0 & 101,2 & 103,6 \\
\hline оптимистический вариант & 101,0 & 101,2 & 101,3 & 101,5 & 105,2 \\
\hline Материалоемкость валового выпуска & & & & & \\
\hline базовый вариант & 99,5 & 99,5 & 99,4 & 99,4 & 97,8 \\
\hline оптимистический вариант & 99,5 & 99,4 & 99,4 & 99,4 & 97,7 \\
\hline $\begin{array}{l}\text { Фондоемкость валового выпуска по основным } \\
\text { фондам }\end{array}$ & & & & \\
\hline базовый вариант & 100,1 & 99,5 & 99,1 & 98,7 & 97,4 \\
\hline оптимистический вариант & 99,4 & 99,0 & 98,0 & 97,3 & 93,9 \\
\hline
\end{tabular}

Источник табл. 3-4: результаты расчетов авторов с использованием ДММ экономики РБ.

При рассмотрении результатов прогнозных расчетов по отраслям необходимо отметить, что в обоих вариантах все отрасли экономики РБ имеют положительный рост в 2019-2021 гг. В 2018 г. незначительное падение объемов прогнозируется в сельском хозяйстве, добыче полезных ископаемых и в производстве и распределении электроэнергии, газа и воды (по базовому варианту), и в обрабатывающих производствах - по обоим вариантам (табл. 4). 


\section{Таблица 4. Темпы роста валового выпуска в Республике Бурятия в 2018-2021 гг. по видам экономической деятельности, \%}

\begin{tabular}{|c|c|c|c|c|c|}
\hline Вид экономической деятельности & 2018 & 2019 & 2020 & 2021 & $\begin{array}{l}2018- \\
2021 \text { гr. }\end{array}$ \\
\hline \multicolumn{6}{|l|}{ Валовой выпуск - всего } \\
\hline базовый вариант & 100,5 & 101,2 & 101,9 & 102,5 & 106,4 \\
\hline оптимистический вариант & 101,6 & 102,2 & 103,4 & 104,3 & 112,0 \\
\hline \multicolumn{6}{|l|}{ Машиностроение фондосоздающее } \\
\hline базовый вариант & 104,5 & 105,0 & 105,0 & 105,0 & 121,0 \\
\hline оптимистический вариант & 104,1 & 106,5 & 105,5 & 106,1 & 124,1 \\
\hline \multicolumn{6}{|l|}{ Строительство фондосоздающее } \\
\hline базовый вариант & 105,0 & 104,0 & 104,0 & 104,0 & 118,1 \\
\hline оптимистический вариант & 107,4 & 106,1 & 106,3 & 106,3 & 128,7 \\
\hline \multicolumn{6}{|l|}{$\begin{array}{l}\text { Сельское хозяйство, охота и лесное хозяйство, } \\
\text { рыболовство, рыбоводство }\end{array}$} \\
\hline базовый вариант & 99,3 & 100,2 & 101,0 & 101,7 & 102,1 \\
\hline оптимистический вариант & 100,3 & 101,0 & 102,2 & 103,2 & 106,9 \\
\hline \multicolumn{6}{|l|}{ Добыча полезных ископаемых } \\
\hline базовый вариант & 99,9 & 100,1 & 100,3 & 100,3 & 100,5 \\
\hline оптимистический вариант & 102,9 & 103,8 & 106,1 & 107,6 & 122,0 \\
\hline \multicolumn{6}{|l|}{$\begin{array}{l}\text { Обрабатывающие производства и прочие виды } \\
\text { экономической деятельности (без фондосоздаю- } \\
\text { щего машиностроения) }\end{array}$} \\
\hline базовый вариант & 99,2 & 99,6 & 100,1 & 100,5 & 99,4 \\
\hline оптимистический вариант & 99,9 & 100,3 & 101,2 & 101,9 & 103,3 \\
\hline \multicolumn{6}{|l|}{$\begin{array}{l}\text { Производство и распределение электроэнергии, } \\
\text { газа и воды }\end{array}$} \\
\hline базовый вариант & 99,6 & 100,3 & 100,9 & 101,5 & 102,3 \\
\hline оптимистический вариант & 100,3 & 100,8 & 101,8 & 102,6 & 105,6 \\
\hline \multicolumn{6}{|l|}{ Строительство нефондосоздающее } \\
\hline базовый вариант & 104,2 & 104,5 & 104,8 & 105,0 & 119,8 \\
\hline оптимистический вариант & 105,4 & 105,4 & 106,2 & 106,6 & 125,7 \\
\hline \multicolumn{6}{|l|}{$\begin{array}{l}\text { Оптовая и розничная торговля; ремонт автотранс- } \\
\text { портных средств, мотоциклов, бытовых изделий } \\
\text { и предметов личного пользования } \\
\end{array}$} \\
\hline базовый вариант & 100,0 & 101,1 & 102,2 & 103,2 & 106,7 \\
\hline оптимистический вариант & 101,7 & 102,8 & 104,2 & 105,4 & 114,9 \\
\hline \multicolumn{6}{|l|}{ Гостиницы и рестораны } \\
\hline базовый вариант & 102,6 & 103,8 & 105,0 & 106,0 & 118,7 \\
\hline оптимистический вариант & 103,6 & 104,7 & 106,3 & 107,6 & 124,2 \\
\hline Транспорт и связь & & & & & \\
\hline
\end{tabular}




\begin{tabular}{|c|c|c|c|c|c|}
\hline \multicolumn{6}{|c|}{ Окончание табл. } \\
\hline Вид экономической деятельности & 2018 & 2019 & 2020 & 2021 & $\begin{array}{l}2018- \\
2021 \text { гг. }\end{array}$ \\
\hline базовый вариант & 101,2 & 102,1 & 102,9 & 103,6 & 110,1 \\
\hline оптимистический вариант & 102,2 & 102,9 & 104,2 & 105,2 & 115,3 \\
\hline \multicolumn{6}{|l|}{ Финансовая деятельность } \\
\hline базовый вариант & 101,0 & 101,5 & 102,0 & 102,4 & 107,1 \\
\hline оптимистический вариант & 101,8 & 102,2 & 103,1 & 103,7 & 111,2 \\
\hline \multicolumn{6}{|c|}{$\begin{array}{l}\text { Операции с недвижимым имуществом, аренда } \\
\text { и предоставление услуг }\end{array}$} \\
\hline базовый вариант & 100,8 & 101,3 & 101,8 & 102,1 & 106,3 \\
\hline оптимистический вариант & 101,7 & 102,0 & 102,9 & 103,6 & 110,5 \\
\hline \multicolumn{6}{|l|}{$\begin{array}{l}\text { Государственное управление и обеспечение } \\
\text { военной безопасности; социальное страхование }\end{array}$} \\
\hline базовый вариант & 101,0 & 102,2 & 103,4 & 104,4 & 111,4 \\
\hline оптимистический вариант & 102,1 & 103,1 & 104,7 & 105,9 & 116,7 \\
\hline \multicolumn{6}{|l|}{ Образование } \\
\hline базовый вариант & 99,3 & 100,5 & 101,7 & 102,6 & 104,1 \\
\hline оптимистический вариант & 100,3 & 101,4 & 102,9 & 104,1 & 109,0 \\
\hline \multicolumn{6}{|c|}{$\begin{array}{l}\text { Здравоохранение и предоставление социальных } \\
\text { услуг }\end{array}$} \\
\hline базовый вариант & 101,6 & 102,9 & 104,0 & 105,0 & 114,2 \\
\hline оптимистический вариант & 102,7 & 103,8 & 105,3 & 106,6 & 119,5 \\
\hline \multicolumn{6}{|c|}{$\begin{array}{l}\text { Предоставлениепрочихкоммунальных, социальных } \\
\text { и персональных услуг }\end{array}$} \\
\hline базовый вариант & 100,3 & 101,2 & 102,0 & 102,8 & 106,5 \\
\hline оптимистический вариант & 101,3 & 102,0 & 103,2 & 104,2 & 111,1 \\
\hline
\end{tabular}

В оптимистическом варианте наибольшие темпы развития за три года ожидаются по следующим отраслям: фондосоздающее строительство (128,7\%), строительство нефондосоздающее (текущий ремонт зданий и сооружений $-125,7 \%$ ), гостиницы и рестораны (124,2\%), машиностроение фондосоздающее $(124,1 \%)$, добыча полезных ископаемых (122\%). Наиболее низкие темпы роста имеют: обрабатывающие производства (103,3\%), производство и распределение электроэнергии, газа и воды $(105,6 \%)$, сельское, лесное хозяйство и рыболовство (106,9\%). Особое внимание обращают на себя высокие показатели отрасли «Гостиницы и рестораны» в обоих вариантах, что свидетельствует о важности развития туристического бизнеса в Бурятии. 


\section{Основные выводы по результатам прогнозных расчетов}

1. Преодоление затяжного спада в экономике РБ возможно на основе существенного наращивания инвестиций. Этот очевидный факт подкрепляется количественными оценками ускоренного экономического роста на региональном и отраслевом уровнях, полученными на основе прогнозных расчетов по ДММ экономики РБ. Эти оценки учитывают межотраслевые связи между отраслями республики и поэтому могут отличаться от прогнозов республиканского правительства, которые такие связи не принимают во внимание. Увеличение темпов прироста инвестиций в основной капитал в 2018-2021 гг. с 13\% по базовому варианту до примерно $21 \%$ по оптимистическому приводит к ускорению темпов прироста ВРП с 9\% до $15 \%$ соответственно, динамика производства предметов потребления и услуг для домашних хозяйств возрастает с $8 \%$ до $13 \%$.

2. Прогнозные расчеты с использованием ДММ с нечеткими параметрами показали очень высокую зависимость динамики валового выпуска и ВРП экономики РБ по отношению к изменению объема инвестиций в основной капитал. Эти результаты подтверждают возможность существенного ускорения экономического роста в РБ за счет резкого наращивания инвестиций.

3. Использование нечеткомножественного подхода при прогнозировании экономики РБ с использованием ДММ позволило выявить достаточно высокую надежность прогноза регионального валового выпуска и по отношению к варьированию инвестиций в основной капитал и сальдо ввоза - вывоза в период 2018-2021 гг. Надежность прогноза для 2021 г. колеблется в пределах $63-78 \%$.

4. Огромное значение инвестиций в основной капитал для экономики РБ демонстрируют также результаты прогнозных расчетов на отраслевом уровне. В оптимистическом варианте наибольшими темпами за весь прогнозный период развиваются фондосоздающее строительство, машиностроение фондосоздающее, строительство нефондосоздающее (текущий ремонт зданий и сооружений).

5. Ускоренный экономический рост в РБ тесно связан с наращиванием объемов валового выпуска таких видов экономической деятельности, как «Гостиницы и рестораны» и «Добыча полезных 
ископаемых». Особое внимание привлекает высокий рост отрасли «Гостиницы и рестораны» в обоих вариантах прогноза, что свидетельствует о важности развития туристического бизнеса в Бурятии и может способствовать постепенной диверсификации источников экономического развития РБ.

6. В целом возрождение экономики в РБ, проявившееся по ряду показателей уже в 2017 г., может опираться на более активную макроэкономическую политику Правительства и Центрального банка России, а также на более энергичные действия по обеспечению экономического роста в регионе со стороны республиканского руководства. Такие действия связаны с включением Бурятии в реализацию ряда федеральных программ и проектов и с привлечением инвестиций отечественных и иностранных инвесторов в различные отрасли республики (более подробно см. выше).

\section{Литература}

Атанов Н. И. Российско-Евразийский транзит экономической зоны великого шелкового пути // ЭКО. 2017. № 4 (514). С. 78-87.

Баранов А.О., Дондоков З.Б.-Д., Дырхеев К. П., Павлов В.Н., Суслов В.И. Методические проблемы формирования информационной базы динамической межотраслевой модели экономики Республики Бурятии // Регион: экономика и социология. 2016. № 4. С. 47-68.

Баранов А.О., Павлов В.Н. Прогнозирование развития экономики России с использованием динамической межотраслевой модели с нечеткими параметрами // Вестник Новосибирского государственного университета. Серия: Социально-экономические науки. 2007. T. 7, Вып. 3. С. 3-14. URL: http://www. nsu.ru/exp/ref/Media:4ef1a2aa8846c8c0130002871_Baranov.pdf

Баранов А.О., Дондоков З.Б.-Д., Дырхеев К. П., Павлов В.Н., Суслов В.И. Построение среднесрочного прогноза развития Республики Бурятии с использованием динамической межотраслевой модели // Регион: экономика и социология. 2017. № 4. С. 177-199.

Беломестнов В.Г., Хардаев К. П. К вопросу о формировании региональной стратегии социально-экономического развития в условиях становления новой экономической политики (на примере Республики Бурятия) // Проблемы современной экономики. 2017. № 1. С. 120-125.

Борисов Г.О., Дондоков З. Б.-Д., Намжилова В. О. Экономический коридор Китай - Монголия - Россия: режим ожидания // ЭКО. 2017. № 5. С. 98-106.

Булатова Н.Н. Перспективы развития региона в условиях формирования экономического коридора «Россия - Монголия - Китай» // Научно-технические ведомости Санкт-Петербургского государственного политехнического университета. Экономические науки. 2017. Т. 10. № 1. С. 90-98. 
Булатова Н.Н., Алексеев А.В., Тихонова П.В. К вопросу формирования экономического коридора «Россия-Монголия-Китай» // Вестник Бурятского государственного университета. Экономика и менеджмент. 2017. № 4. С. 33-40.

Булатова Н.Н., Тихонова П.В. Проблемы и основные положения формирования стратегии социально-экономического развития регионов (на примере Республики Бурятия) //Научно-технические ведомости Санкт-Петербургского государственного политехнического университета. Экономические науки. 2017. Т. 10. № 6. С. 106-118.

Дондоков З. Б.-Д., Потапов Л.В., Кислов Е.В. Минерально-сырьевой комплекс Республики Бурятия: состояние и перспективы развития // Минеральные ресурсы России. Экономика и управление. 2015. № 6. С. 43-51.

Дондоков 3.Б.-Д., Борисов Г.О. Хозяйственное освоение зоны БАМ: проблемы и перспективы комплексного освоения севера Байкальского региона // Региональная экономика. 2015. № 48. С. 15-25.

Дондоков 3. Б.-Д. Социально-экономическое развитие Республики Бурятия и охрана озера Байкал: в одну телегу впрячь ли можно, коня и трепетную лань? // Вестник БНЦ СО РАН. 2017. № 2. С. 91-96.

Дондоков З.Б.-Д., Даваасурэн А., Дареев Г.Е., Смолин В.В. Проблемы и перспективы развития транспортно-логистической системы Улан-Удэ-УланБатор - Эрлянь // Вестник Бурятского научного центра Сибирского отделения Российской академии наук. 2017.№ 4 (28). С. 126-133.

Пуниукова С. Д., Жамьянов Д. Ц.-Д., Дарбалаева Д. А. Предложения по совершенствованию регионального финансового механизма использования, охраны и воспроизводства лесных ресурсов // Проблемы региональной экологии. 2015. № 4. С. 72-77.

Стратегия регионального развития: Республика Бурятия - 2015 /Под общ. ред. А. Г. Гранберга, П. А. Минакира, Л. В. Потапова, Дальневост. отд-ние, Ин-т экон. исследований. М.: Экономика, 2005. 664 с.

Сангадиева И.Г. Стратегические ориентиры социально-экономического развития региона // Экономика и предпринимательство. 2016. № 11-2 (76-2). C. $1127-1130$.

Таханова С.С., Шаралдаева И.А. Вопросы управления развитием минерально-сырьевой базы нефритовой отрасли Республики Бурятия. Вестник ВСГУТУ. 2016. № 5 (62). С. 141-148.

Статья поступила 30.07.2018.

\section{Summary}

Baranov A.O., Institute of Economics and Industrial Engineering, SB RAS, Novosibirsk State University, Dondokov Z. B.-D. Buryatia Scientific Center SB RAS, Ulan-Ude, Pavlov V.N. Institute of Economics and Industrial Engineering, SB RAS, Suslov V.I. Institute of Economics and Industrial Engineering, SB RAS, Novosibirsk State University, Novosibirsk

Prospects for the Development of the Economy of the Republic of Buryatia

The article analyzes the development of the economy of the Republic of Buryatia in 2007-2017. Next, the results of forecast calculations of the development of the republic for the period up to 2021 are presented and analyzed in two versions - basic and optimistic. Forecast calculations were performed using the dynamic input-output 
model of the economy of the Republic of Buryatia with fuzzy parameters developed by the authors. The paper shows that under favorable macroeconomic conditions and a sharp increase in investment in fixed assets, a significant acceleration of economic growth in Buryatia is possible. Specific projects that will accelerate economic growth in the republic are discussed.

Analysis and forecasting of the regional economy; Republic of Buryatia; dynamic input-output models

\section{References}

Atanov N.I. (2017). Russian-Eurasian transit of the economic zone of the Great Silk Road ECO. [ECO]. No. 4. Pp. 78-87. (In Russ.)

Baranov A.O., Dondokov Z.B.-D., Dyrkheev K.P., Pavlov V.N., Suslov V.I. (2016). Methodical problems of formation of the information base of the dynamic interindustry model of the economy of the Republic of Buryatia. Region: ekonomika i sotsiologiya. [Region: economy and sociology]. No. 4. Pp. 47-68. (In Russ.)

Baranov A. O., Pavlov V.N. (2007). Forecasting the development of the Russian economy using a dynamic interindustry model with fuzzy parameters. Vestnik Novosibirskogo gosudarstvennogo universiteta. Seriya: Sotsialnoekonomicheskie nauki [Bulletin of Novosibirsk State University. Series: Socioeconomic sciences] V. 7. No. 3. Pp. 3-14. Available at: http://www.nsu.ru/exp/ref/ Media:4ef1a2aa8846c8c0130002871_Baranov.pdf. (In Russ.).

Baranov A.O., Dondokov Z.B.-D., Dyrkheev K.P., Pavlov V.N., Suslov V.I. (2017). Construction of a medium-term forecast of the development of the Republic of Buryatia using a dynamic interindustry model. Region: ekonomika i sotsiologiya. [Region: economy and sociology]. No. 4. Pp. 177-199. (In Russ.)

Belomestnov V.G., Khardaev K.P. (2017). On the issue of the formation of a regional strategy for social and economic development in the conditions of the formation of a new economic policy (on the example of the Republic of Buryatia). Problemy sovremennoi ekonomiki. [Problems of modern economy]. No. 1. Pp. 120-125. (In Russ.)

Borisov G. O., Dondokov Z.B.-D., Namzhilova V.O. (2017) Economic corridor China - Mongolia - Russia: standby mode. ECO. [ECO]. No. 5. Pp. 98-106. (In Russ.)

Bulatova N.N. (2017). Prospects for the development of the region in the formation of the economic corridor "Russia - Mongolia - China". Nuachno-tekhnicheskie vedomosti Sankt-Peterburgskogo gosudarstvennogo politekhniocheskogo universiteta. Ekonomicheskie nauki. [Scientific and technical lists of the St. Petersburg State Polytechnic University. Economicsciences]. V. 10. No. 1. Pp. 90-98. (In Russ.)

Bulatova N.N. (2017), Alekseev A.V., Tikhonova P. V. On the formation of the economic corridor "Russia-Mongolia-China". Vestnik Buryatskogo gosudarstvennogo universiteta. Ekonomika i menedgment. [Bulletin of Buryat State University. Economy and Management] No. 4. Pp. 33-40. (In Russ.)

Bulatova N.N., Tikhonova P.V. (2017), Problems and main provisions for the formation of a strategy for social and economic development of regions (on the example of the Republic of Buryatia). Nuachno-tekhnicheskie vedomosti SanktPeterburgskogo gosudarstvennogo politekhniocheskogo universiteta. Ekonomicheskie 
nauki. [Scientific and technical lists of the St. Petersburg State Polytechnic University. Economic sciences]. V. 10. No. 6. Pp. 106-118. (In Russ.)

Dondokov Z.B.-D., Potapov L. V., Kislov E. V. (2015). Mineral and raw materials complex of the Republic of Buryatia: state and development prospects. Mineralnye resursy Rossii. Ekonomika I uopravlenie [Mineral resources of Russia. Economics and Management]. No. 6. Pp. 43-51. (In Russ.)

Dondokov Z.B.-D., Borisov G. O. (2015) Economic Development of the BAM Zone: Problems and Prospects for the Integrated Development of the North of the Baikal RegionRegionalnayaekonomika [Regional economic] No. 48. Pp. 15-25. (In Russ.)

Dondokov Z. B.-D., Davaasuren A., Dareev G. E., Smolin V.V. (2017) Problems and prospects of the development of the transport and logistics system of Ulan-UdeUlan Bator - Erlian. Vestnik Buryatskogo nauchnogo tsentra SO RAN [Bulletin of the Buryat Scientific Center of the SB RAS]. No. 4. Pp. 126-133. (In Russ.)

Puntsukova S.D., Zhamyanov D. Ts.-D., Darbalaeva D.A. (2015) Proposals for the improvement of the regional financial mechanism for the use, protection and reproduction of forest resources. Problemy regionalnoi ekologii [Problems of regional ecology]. No. 4. Pp. 72-77. (In Russ.)

Regional Development Strategy: Republic of Buryatia - 2015. (2005). Ed. Granberg A.G., Minakir P.A., Potapova L.V. Russian Academy of Sciences, Far East Division, Institute of Economic Research M.: Ekonomika. 664 P. (In Russ.)

Sangadieva I. G. (2016) Strategic guidelines for the socio-economic development of the region Ekonomika I predrinivatelstvo [Economics and Entrepreneurship]. No. 11-2 (76-2). Pp. 1127-1130. (In Russ.)

Takhanova S. S., Sharaldaeva I.A. (2016) Issues of managing the development of the mineral and raw materials base of the jade branch of the Republic of Buryatia. Vestnik Vostochno-Sibirskogo gosudarstvennogo universiteta Tekhnologii I upravleniya [Bulletin of the Eest-Siberian State University of Technology and Management $]$ No. 5. (62), Pp. 141-148. (In Russ.) 